\title{
A HALlgatóK PÁlyaVÁlaszTását BEFOLYÁSOLÓ SZEMPONTOK ELEMZÉSE
}

\author{
Pividaychyk Oxana, Popovich Anna, Báthori-Tárczy Zita, Afanasyev \\ DMITRO
}

\begin{abstract}
A study was conducted among students of the Uzhhorod National University and Beregszasz II Rakoczi Ferenc Institution (Ukraine) as part of a framework for international academic cooperation. The study was a joint project of faculty from Uzhhorod National University and Debrecen University in Hungary and focused on work value preferences and career choices. In the pilot study, we examined the professional motivations of students using a questionnaire developed by Debrecen University professors. The questionnaire used in this study included evaluation dimensions of post-graduation content as well. The study provided an ability to rank the information sources used by students when making career choices. The results clearly demonstrate that the most important sources of information regarding career choices were teachers, parents, and admission pamphlets. Results also showed that students chose to get a diploma in order to avoid unemployment. More than half of the respondents were actually interested in their chosen specialty. The results showed that the reason why respondents chose particular institutions of high learning was due to the respective institution offering the best in specialty training and the best reputation. The majority of respondents thought their profession provided a wide range of choices and high prestige though only about half of respondents wanted to work in the identified field of study. The results highlighted the importance of the development of professional motivation along with personal and professional skill development thereby increasing the effectiveness of professional social work practice. This research topic has attracted a high level of practical interest, thus the continuation of this study on an expanded sample would be justifiable, not only in Transcarpathia, but also in other prestigious academic institutions in Ukraine. A comparative analysis of humanitarian and student images of the profession, motivation for study and research would also be of interest.
\end{abstract}

Keywords: work values, work value preferences, professional motivations, image of the profession, prestige of the university branches

DOI: $10.19055 / \mathrm{ams} .2013 .4 / 10 / 5$ 


\section{BEVEZETÉS}

Jelen tanulmányunk a Debreceni Egyetem és az Ungvári Nemzeti Egyetem közötti nemzetközi együttmüködés keretében 2012-ben végzett kutatás eredményeként született, és szervesen illeszkedik a Debreceni Egyetemen a 2000/2001-es tanévben indult tehetséggondozási program keretében vizsgált kérdésekhez (Balogh -Fónai 2003, Fónai 2009). A vizsgálatba, az Ungvári Nemzeti Egyetem és a Beregszászi II. Rákóczi Ferenc Főiskola azon diákjai kerültek be, akik a bachelor diplomájukat szerzik (negyedik évfolyam) valamint azok, akik tovább tanulnak és a „szpecialiszt” diplomájukat szerzik (ötödik évfolyam). Jelenleg az adott szakokon mesterképzés nem folyik, a legmagasabb fokozat a „szpecialiszt” fokozat, amit a diákok 10 szemeszter sikeres befejezése után kapnak. A kutatás így kialakult mintájának összetétele jól tükrözi a szakokon tanuló hallgatók nemek szerinti eloszlásának sajátosságát és a humán szakok elnőiesedését.

A kutatás során, a Debreceni Egyetemen a tehetséggondozó program (DETEP) hallgató beválogatási eljárásában alkalmazott, a szakmai motivációit vizsgáló kérdőív, adaptált változatát alkalmaztuk. Jelen tanulmány a hallgatók motivációit vizsgáló kérdőív feldolgozása során kapott jelentősebb eredményeket tárgyalja. Az elemzésünk meghatározó módon leíró jellegü.

\section{MóDSZER ÉS MINTA}

\section{A vizsgálati minta}

A tanulmány elemzi az Ungvári Nemzeti Egyetem negyed és ötödéves szociális munka, pszichológia, matematika és turizmus szakos valamint a Beregszászi II: Rákóczi Ferenc Főiskola hallgatóinak a DETEP hallgatói beválogatások során alkalmazott kérdőív adaptált változatának nyitott és zárt kérdéseire adott válaszait. A kísérleti tanulmányban 138 hallgató vett részt, közülük $25,2 \%$ férfi és $74,8 \%$ nő. . A válaszadók több mint fele 19-20 éves, a kor szerinti eloszlásuk aránya a következő: 19 évesek - 21,4\%, 20 évesek - 35,1\%, 21 év felettiek - 43,5 \%. A legtöbb válaszadó szociológia és szociális munka szakos hallgató, arányuk a megkérdezettek körében 35,9\%, további 35,9\% a humán tudományok képviselője, pedagógia, pszichológia szakos hallgató. A természettudományi karok diákjai 19,8\% arányban vettek részt a felmérésben, a társadalomtudományi, jogi és politológia szakos hallgatók aránya $6,9 \%$.

\section{A vizsgálat módszere}

A Debreceni Egyetem Balogh László vezetése alatt álló szakmai grémiuma által kidolgozott kérdőív 53 itemből áll Kidolgozásában a Debreceni Egyetem oktatói, Mező Ferenc, Fónai Mihály és Márton Sándor, a hazai tehetséggondozás ismert szereplői vettek részt (Márton et al. 2006, Fónai 2010)]. A kérdőív a tehetségazonosítás, a tehetséggon- 
dozás és a tehetségazonosítással összefüggő motivációs kérdésekre koncentrál, de tartalmaz a szülők foglalkoztatási helyzetére valamint, a felsőoktatás változásaira és a felvételi rendszer módosulásaira vonatkozó kérdéseket is. A kérdőív a professziókhoz szükséges tudást, a professziók előnyeit és hátrányait is vizsgálja, erre elsősorban nyitott kérdéseket alkalmaz. A kérdőív dimenziói tartalmazzák továbbá a demográfiai és azonosító kérdéseket, az iskolai életúttal, pálya-és egyetemválasztással, egyetemi felvétellel, a választott szakról és szakmáról szóló véleményekkel és elvárásokkal, egyetemi tapasztalatokkal és életúttal kapcsolatos kérdéseket is (Fónai - Márton 2010). A hallgatók pályaképről alkotott véleményének jellemzése a pályaválasztási motivációjuk, a szakkal és szakmával való megelégedettségük, a pályán maradási szándékuk valamint, a szakmai tevékenységük célját tükröző kritériumok alapján történik. Az alapmegoszlásokat az egyes jelentések választási gyakorisága alapján a teljes mintára vonatkozóan elemezzük. A hallgatók véleményére, attitüdjeire vonatkozó kérdések értékelésére a kérdőívben különböző osztású (4-10) skálák találhatók.

\section{A hallgatók PályaVálasztásnál ALKALMAZOTT SZEMPONTJAINAK ELEMZÉSE}

A vizsgálat lehetőséget adott a pályaválasztáskor a hallgatók által alkalmazott információforrások rangsorolására. A hallgatók, a kérdésekre válaszolva, a 12 lehetséges információforrás fontosságát osztályozták a pályaválasztásuk szempontjából, egy 4-fokozatú skálán, ahol az 1-es a legkevésbé fontos, a 4-es a legfontosabbat jelenti.

A kapott eredmények arról tanúskodnak, hogy a hallgatók számára legfontosabb szempontok, amelyek alapján pályát választottak, az információforrás, a szakmaválasztás oka, a szakmáról kialakított kép, valamint, a választott szak elsajátításához szükséges tapasztalat. (1. ábra)

A hallgatók válaszai alapján kiszámított átlagos pontszámok egyértelmủen kimutatták, hogy legkevésbé az olyan forrás, mint a nyílt napok $(1,06)$,a szakma kiemelkedő képviselőjétől $(1,42)$, a szakma családi képviselőjétől kapott információ $(1,489)$ játszott szerepet. Sőt meglepő módon, az internetről $(1,545)$ kapott információ sem sokat számított. Ellentétben pl. Magyarországgal, ahol mára már az internet a legfontosabb információforrás a fiatalok számára, ebben a tekintetben is. Viszont döntő jelentőséggel bír a szakma választása szempontjából az iskola, a tanár $(2,511)$ mint forrás, "a sok helyröl " kapott információ $(2,33)$ a felvételi tájékoztatóból $(2,17)$, valamint a szülőktől kapott információ (2.136). A kapott eredmény fényt derít arra, hogy mi áll a pályaválasztási döntések hátterében, hogy milyen mértékben hatnak a különböző tényezők a hallgatók szak- és iskolaválasztási preferenciáinak alakulására. (2. ábra)

A szakma kiválasztásánál szerepet játszó további szempontok vizsgálata céljából a válaszadókat arra kérték, hogy azonosítsák azokat a kritériumokat, amelyek fontos szerephez jutottak a pályaválasztásuknál. Az egyes befolyásoló tényezőknek 4-fokozatú skálán mért pontátlagait összehasonlító grafikont tartalmazó ábrán közöljük, mert érde- 
kes különbséget mutat. A két intézmény hallgatóinak összehasonlításakor kiderül, hogy bár ugyanazt a két tényezőt tartották fontosnak a választáskor, a hangsúly mégis teljesen más. A beregszászi hallgatók az elképzelések megvalósítását tartják a legfontosabbnak, míg az ungvári hallgatók elsősorban a felvételi tárgyak miatt döntöttek a választott szak mellett. Nem csak a sorrend cserélödött fel, hanem az átlagok közötti kü lönbség is ennél a két tényezőnél a legnagyobb a két csoport között.

1. ábra. A pályaválasztásnál használt információforrásoknak tulajdonított fontosság átlagértékei.

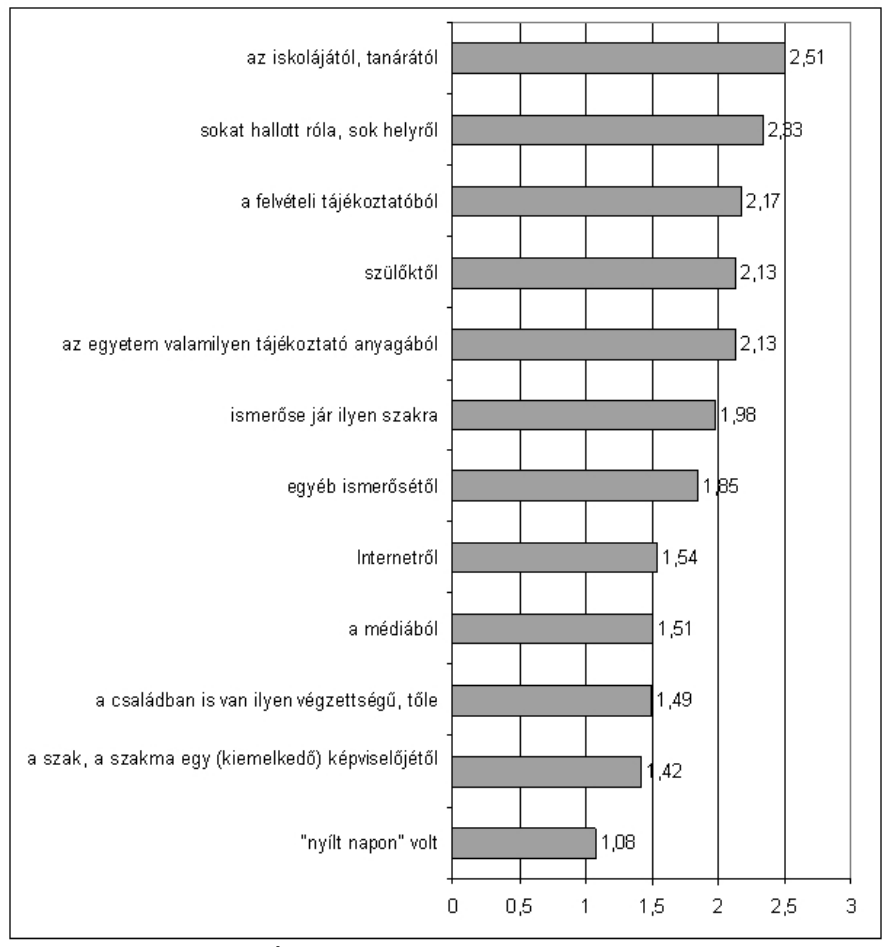

Forrás: A TÁMOP 4.2.2-B pályázati kutatás adatbázisa

A gyakoriság értékei közül csak a legfontosabbakat közöljük, mivel kis számúak, ezért nem foglaltuk táblázatba, csak szövegben jelenítjük meg. A hallgatók 39,1 \%-a számára az a válasz, mi szerint " a felvételi tárgyak a kedvencei " döntő fontosságúnak, 21,1 \% számára nagyon fontosnak bizonyult. Az " így tudja megvalósítani elképzeléseit " választ a hallgatók 29,2 \%-a döntően, 36,9\%-a pedig nagyon fontosnak tartja. Ezen válaszokat adók jelentős többsége középiskolák végzőse. 
2.ábra A szakválasztást befolyásoló tényezők átlagértékei

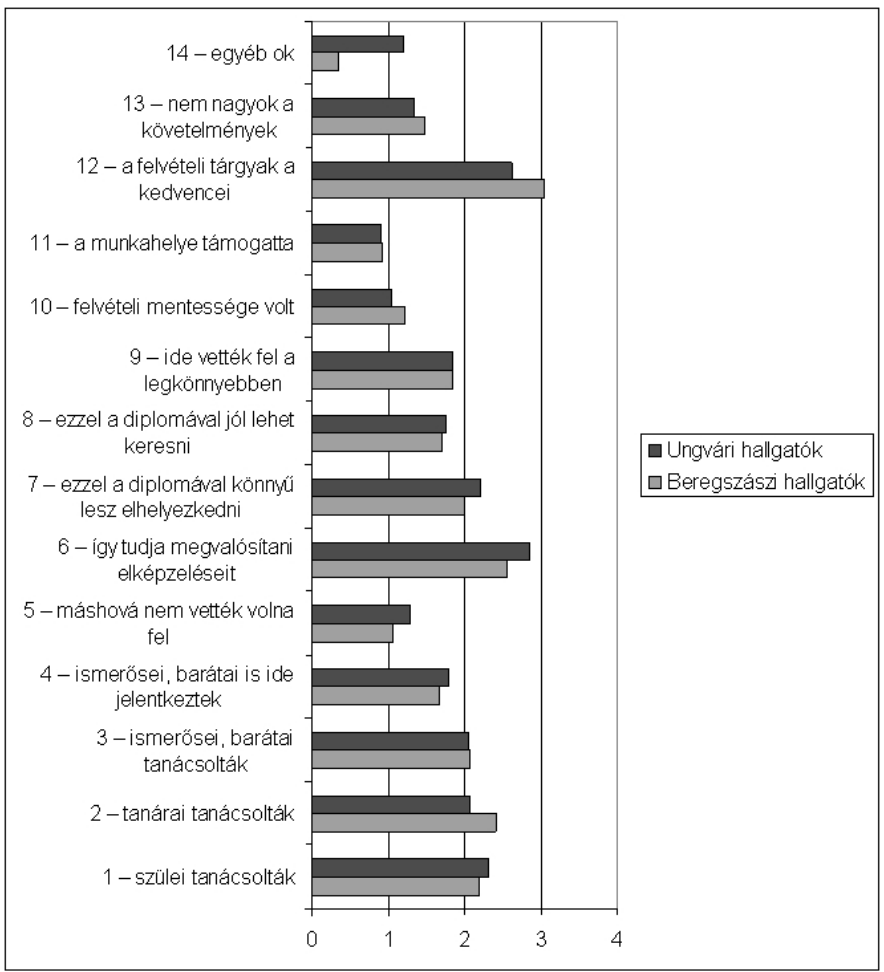

Forrás: A TÁMOP 4.2.2-B pályázati kutatás adatbázisa

Ukrajna oktatási rendszere az egyetemekre való jelentkezést, épp úgy, mint Magyarországon, csak érettségivel rendelkező hallgatók számára teszi elérhetővé. Érettségizni középiskolákban, szakközépiskolákban, gimnáziumokban, líceumokban valamint más típusú középszintü oktatási intézményben lehet [(Orosz 1992.) Ismeretes, hogy a különböző típusú intézmények oktatási szintje, követelményrendszere jelentősen különbözik, amit az egyetemi felvételinél az emelt szintü érettségi, vagyis a tanulók teljesítményének külső független tesztelése próbál áthidalni.

Tapasztalatunk azt mutatja, hogy az évfolyamokon belül komoly eltérés van a hallgatók teljesítményében, ezért érthető, hogy nagy jelentőséggel bírnak számukra a követelményekkel kapcsolatos kérdések. A legszembetünőbb tényező volt, hogy a gimnáziumot végzettek 85 7\%-a a szülei tanácsára választotta a szakját, ami a társadalmi 
tőke „továbbhalmozását” jelezheti, míg pl. a szakközépiskolában érettségizettek harmada a barátok tanácsát tartotta fontosnak. (Bordieu 1998.) A szakközépiskolában végzett hallgatók ugyancsak mintegy harmada választotta a nem túl nagy követelmények adta viszonylagos könnyebbséget. A jó kereseti lehetőséget választotta a gimnáziumot végzettek csaknem fele, ez a szempont a szakokat tekintve a jogi és társadalomtudományi képzésekben lévőket ambicionálta, több mint $55 \%$-os gyakorisággal.

A kutatás kiterjedt arra is, hogy a konkrét oktatási intézmény kiválasztására, a felsőoktatási intézménybe való jelentkezésre milyen más tényezők vannak hatással. A hallgatók több, az egyetemre való bekerülésüket befolyásoló tényezők közül választhattak. (3. ábra)

3. ábra Az intézményválasztást befolyásoló tényezők átlagértékei

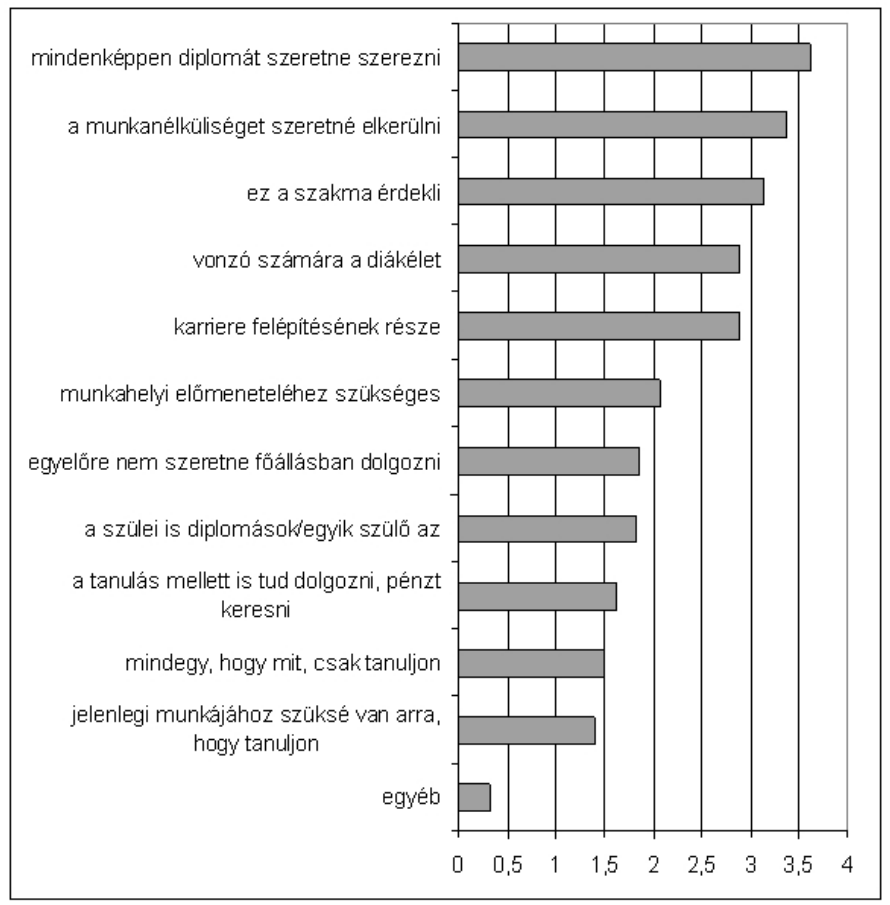

Forrás: A TÁMOP 4.2.2-B pályázati kutatás adatbázisa

A karok szerinti eloszlástól függetlenül, a hallgatók választásának sorrendje alapján elmondható, hogy a válaszadók a rangsorban a legelökelöbb helyre a diploma megszerzését tették (átlagérték 3,62), a diploma megszerzését továbbá fontosabbnak tartják a 
szakma iránt érzett érdeklődésnél $(3,13)$, ám nem mindegy számukra, hogy mit tanulnak. Az utóbbi kijelentésnél a hallgatók válaszai alapján kiszámított átlagérték $(1,49)$, ami a többihez viszonyítva igen alacsonynak számít. Jelentős azoknak a hallgatóknak a száma, akik a munkanélküliséget szeretnék elkerülni $(3,37)$. Az eredmények arra utalnak, hogy a felsőoktatási intézményben a tanulást sok hallgató csak azért választja, mert ezt a munkanélküliség elkerülésének egyik módjának tartja, ugyanakkor egyértelművé teszi, hogy a diploma megléte komoly esély a munkaerőpiacon. A hallgatók válaszai alapján kapott eredmények azt mutatják, a felsőoktatási intézménybe való bekerülésnél a munkahelyi elömenetel közepes fontosságú $(2,07)$ míg a vonzó diákéletet a 12 különböző pozíciót számláló rangsorban a negyedik, átlagértéke 2,88, ami megegyezik a „karriere építésének része” esetében kiszámított átlagértékkel. Az alacsony átlagérték a ,jelenlegi munkájához szükség van arra, hogy tanuljon” kijelentésnél $(1,39)$ arra enged következtetni, hogy a hallgatók úgy vélik, a már munkával rendelkezők számára nem fontos a tanulás, továbbá a diploma megszerzése nem javítana a helyzetükön. Véleményünk szerint azt, hogy a hallgatók nem tartják komoly befolyásoló tényezőnek azt, hogy a tanulás mellett dolgozhatnak (az átlagérték itt 1,63) az magyarázza, hogy egyfelől nem bíznak abban, hogy a tanulás mellett egyáltalán tudnának munkát találni, másfelöl, tapasztalataik e téren nincsenek a felvételizésnél, így nem is gondolnak arra, hogy ezt a tanulás mellett megtehetik. Ukrajnában a felsőoktatásban tanulók jelentős része az egyetemi évei révén próbálja elkerülni a munkanélküliséget, bízva abban, hogy a gazdasági és munkaerő-piaci helyzet a tanulásuk évei alatt kedvezően változik. Az eredmények értékelésénél fontos információnak tartjuk azt, hogy a társadalomtudományok, jog, politológia szakos hallgatók csupán 44,4\%-ának véleménye alapján számít az egyetemen tanulás a karrierépítés szerves részének. A leendő szociológia és szociális munka szakos hallgatók mindössze 39,1\%-a tartja a szakmát érdekesnek. Ezek a számok újra felhívják a figyelmet arra, hogy az egyéni és szakmai képességfejlesztésen túl, ami a gyakorlati szociális munka eredményességének növelését eredményezheti, nagy szükség van a szakmai motiváció fejlesztésére is, ami növelheti a végzett szakemberek pályán maradási esélyeit.

\section{SZAKOK RANGSOROLÁSA HALLGATÓIK ÉRTÉKELÉSE ALAPJÁN}

A legtöbb válaszadó úgy véli, az általa választott szak az oktatási intézményen belüli többi szak, szakma rangsorában megfelelő helyet foglal el. A tízfokozatú skálán (amely szerint az 1 - ismeretlen, legkevésbé elismert szakot, a 10 - az elit, legelismertebb sza kot jelöli) a hallgatók a saját szakjukat átlagosan 7. 4-re értékelték, azaz elég magasan pontozták a skálán. A hallgatóik értékelése alapján a szakok a következö rangsorba kerültek: A szociológia és szociális munka szakos hallgatók saját szakjukat átlagosan a tízes skálán ötre becsülték, ami a többi szakhoz képest messze a legalacsonyabb pontszámot, azaz helyezést jelent. Ez a szám a szakma kevéssé ismertségén és társadalmilag alacsony szintü elismertségén túl a munkaerő-piaci viszonyokat, a hallgatók elhelyezkedési lehetôségeinek hiányát is mutatja. Ez komoly üzenet a szakmának a társadalomba való beintegrálódása szempontjából.. A humán, pedagógia és a pszichológia szakos hallgatók érté- 
kelése alapján a szakjuk átlagosan nyolcas helyezést kapott, ugyanúgy mint a társadalomtudományok, jog, politológia és a menedzsment szakok. A legelőkelőbb, kilences helyezést, a természettudományi szak kapta. A szaknak ezt a helyezését az magyarázza, hogy az országban még mindig az egzakt tudományok, azaz a bennünket körülvevő természet megismerése kap prioritást, az ember megismerésével, megsegítésével szemben. A kapott eredmények alapján elmondható, hogy ez utóbbiak fontosságát a hallgatók kevésbé érzik a társadalom részéről aktuálisnak. Kérdés, hogy valamiféle „posztmaterialista” tendenciáról, vagy a bennünket körülvevő világ, kétségtelenül meghatározó tudományos-technikai vívmányainak pozitív értékeléséről van szó.

Fontosnak tartjuk a következőkben kifejteni a rangsorolás legfontosabb indokait is, mivel ezek sok esetben, véleményünk szerint, megmagyarázzák a hallgatók fent elemzett értékeléseit, valamint azért, mert több más kérdésben is erösen kihatnak a vélemények alakulására. A megkérdezettek $87 \%$-a jelzi, hogy a szakjuk kevéssé elismert az egyetem többi szakja között, 84,8\%-a választotta a „szakma nem divatos” válaszlehetőséget, 82,6\% pedig szakát ,átlagos helyzetü szak”-ként értékeli. Ez kissé ellentmond a magas elismertségi pontszámoknak. A válaszadók 26,1\%-a tartja „nehéz szaknak", és 17,4\%-a mutat rá arra, hogy az emberek nem rendelkeznek információval a szakkal kapcsolatban, „nem is ismerik, nem tudják, milyen”. Emellett a válaszadók 32,6\%-a tartja azt, hogy a szakon van lehetőség „érdekes tárgyak és ismeretanyag” megismerésére, $23,9 \%$ véli azt, hogy az oktatás színvonalas, 30,4\% szerint a hallgatók összetartóak, jó csapatot alkotnak.

A hallgatók szerint a szak rangját több tényezö alakítja. Nagyjából a felüknél a legfontosabb alakító tényezők közé a hasznosítható ismeretek (54,3\%), az érdekes tárgyak és ismeretanyag $(51,2 \%)$, illetve a jó tanár-diák viszony (47,3\%) és az oktatás színvonala $(43,4 \%)$ tartozik. Mintegy harmaduknál a szak nehézsége $(35,7 \%)$, a magas követelmények (33,3\%), valamint az elismert, színvonalas oktatók $(31,0 \%)$. jelentik a legfőbb rangot. A válaszadók nagyon csekély hányada szerint a szak rangját gyakorlati lag nem befolyásolja: az oktatás alacsony színvonala $(0,8 \%)$, a alacsony szintü követelmények (1,6\%),illetve az, hogy a szak könnyü $(1,6 \%)$, vagy hogy csak föiskolai szak (2, $3 \%)$, esetleg a rossz hírneve " $(2,3 \%)$ stb.

\section{A SZAKOK KÜLSŐ ÉS BELSŐ MEGÍTÉLÉSE}

A kutatás során lehetőség nyílt a szakok külső, vagyis más szakok hallgatói véleményének, valamint a belső, vagyis a hallgatók véleményének alapján való megítélésére. A sztereotip állításokat mindkét esetben maguk a megkérdezett hallgatók rangsorolták egy tízfokozatú skálán. A skálaátlagok által kialakult rangsorolás során a választott szakra jellemző vonások is meghatározásra kerültek. A felmérés során a válaszadókat arra kérték, hogy értékeljék ugyanezen sztereotip állításokat abból a szempontból, hogy mit gondolnak, vajon más szakok hallgatói hová sorolják a szakjukat. Az eredményeket az 1 . táblázat mutatja. 
1. táblázat A szakról alkotott sztereotip állítások skálaátlagai a hallgatók véleménye szerint.

\begin{tabular}{|l|c|c|}
\hline Állítások & $\begin{array}{l}\text { Hallgatók } \\
\text { véleménye }\end{array}$ & $\begin{array}{l}\text { Mások vélekedése, } \\
\text { a hallgatók szerint }\end{array}$ \\
\hline „Nehéz szak” & 7,2 & 6,1 \\
\hline "Összetartó csapat, jó a csapatszellem" & 6,1 & 5,9 \\
\hline "Csak diplomát akarnak szerezni" & 4,8 & 5,7 \\
\hline "Nyüzsögnek az egyetemi közéletben" & 4,7 & 5,2 \\
\hline "Végzés után könnyen boldogulnak" & 4,5 & 4,8 \\
\hline "Jó anyagi hátterük van" & 4,1 & 4,5 \\
\hline "Sok a szabadidejük, ráérnek" & 3,3 & 4,9 \\
\hline A hallgatók "dinasztiákból" érkeznek* & 3,1 & 3,5 \\
\hline "A magolás az elsődleges" & 3,0 & 4,2 \\
\hline "Link szak" & 2,5 & 3,7 \\
\hline
\end{tabular}

Forrás: A TÁMOP 4.2.2-B pályázati kutatás adatbázisa

A táblázat két oszlopában felsorolt értékek azt mutatják, hogy a hallgatók véleményét és a más szakok hallgatóinak véleményét mutató skálaátlagok minden kérdés esetében eltérnek egymástól. A legmarkánsabban az eltérés a hallgatók szabadideje mennyiségének $(1,6)$, szak linkségének, a magolás elsődlegessége $(1,2)$ valamint, a szak nehézségének $(1,1)$ a megitélésében mutatkozik, viszont a rangsorolás az első négy helyezést illetően megegyezik, és mindössze hat esetben mutat csekély eltérést. A mások véleményének hallgatók által feltételezett véleménye alapján kialakult rangsorban két hellyel feljebb került a „Sok a szabadidejük, ráérnek" és „A hallgatók "dinasztiákból" érkeznek" állítás valamint, egy hellyel feljebb a "Végzés után könnyen boldogulnak" és a "Jó anyagi hátterük van" állítás, és egy-egy hellyel került feljebb a "Link szak" és a "A magolás az elsődleges" állítás. A kutatás arra derít fényt, hogy a hallgatók csak két állítás esetében értékelik a mások véleményét a magukénál alacsonyabb skálaátlaggal, viszont nyolc esetben az állítások skálaátlaga magasabb a szakra jellemző állításokkal kapcsolatban. A hallgatók általi rangsorolás egyértelmüen kimutatja, hogy szakjukat csak kevesen sorolják a link szakok közé (az átlagérték 2,5, ami az összes érték között a legalacsonyabb), míg a mások véleményének e kérdésben általuk meghatározott átlaga viszonylag magas $(3,7)$. Ez az érték azt tükrözi, hogy a szakjukat mások által kevéssé elismertnek vélik. A más szakok hallgatóinak véleményével szemben, maguk a hallgatók nem értékelik magas átlagértékkel a magolás elsődlegességét sem, épp úgy, ahogy azt sem, hogy sok lenne a szabadidejük. A skálaátlagok közötti legkisebb kü- 
lönbségek a ,jó csapatszellem” $(0,2)$ valamint „a végzés után könnyen boldogulnak" $(0,3)$ állítások esetében tapasztalhatóak, ami arról tanúskodik, hogy ebben a kérdésben a hallgatók a véleményeket közelieknek vélik. Mindez megfelel a klasszikus „,cselekvő-megfigyelő” torzításnak, ami még akkor is megjelenik, ha csak belegondoljuk magunkat a külső szemlélő szerepébe.

A választott szaknak az egyetemi közvélemény által történő besorolását a válaszadók többsége viszonylag magas átlagponttal képzelte.. Így a tíz pontos skálán (ahol 1 - a legalacsonyabb rangsorban lévő, 10 - a legrangosabb) ez a mutató 6,6. A hallgatók úgy vélik, hogy az egyetem közvéleménye a szakot elsősorban a hasznosítható ismeretek (48,4\%), másrészt a magas színvonal (36,7\%), továbbá az érdekes tárgyak és ismeretanyag (32,0\%) miatt értékeli magasra. Annak nehézsége $(29,7 \%)$, valamint a jó tanár-diák viszony $(28,1 \%)$ esetleg a magas követelmények $(25,8 \%)$ is fontos tényezöknek számítanak.. A hallgatók vélekedése szerint, a szak értékelésének a közvélemény általi kialakítására nincs hatással a kialakult rossz hírnév $(0,8 \%)$, az, hogy csak föiskolai szak $(0,8 \%)$. Az sem sokat számít, hogy ha magas az általános presztízs $(1,6 \%)$, hogy a hallgatók dinasztiákból érkeznek $(1,6 \%)$. Ugyanígy az alacsony színvonalú oktatás $(2,3 \%)$, és a szak könnyü volta $(2,3 \%)$ sem.

\section{A hallgatóK TanUláshoz}

\section{ÉS SZAKMÁJUKHOZ VALÓ HOZZÁÁLLÁSÁNAK MÉRÉSE}

A kutatás keretében igyekeztük felmérni a hallgatók tanuláshoz való hozzáállását különböző mutatók segítségével. Az összesített adatokat (átlagos érték minden állítás esetén) a 4. ábra mutatja.

A kapott eredmények azt mutatják, hogy a hallgatók elvárása az egyetemi évekkel szemben az, hogy megkapják a diplomájukat. A skálaátlag 3.6. A második helyen szerepelnek az egyetemi évek alatti baráti kapcsolatok, ami ennek a tényezőnek a meghatározó szerepét jelzi az elvárások körében $(3,512)$. Ez egyébként a jelen tanulmányban nem elemzett munkaérték vizsgálatban is megjelenik elég előkelő helyen. A jó tanulmányi átlag 3,2-es értéke, a saját magukkal szemben támasztott, valamint erőfeszítéseik elismerésével kapcsolatos elvárásokat tükrözi. Ez az érték csak kevéssé marad el a választott szakmára való felkészülés skálaátlagától $(3,192)$, ami szintén elég magasnak mondható. A rangsorban az utolsó pozíciót foglalja el a város lehetőségei $(2,23)$, ami nem meglepő, annak ellenére, hogy a művelődés lehetőségeinek kihasználása jelentősebb skálaátlaggal rendelkezik. Feltételezésünk szerint ez azért alakult így, mert a müvelődés lehetőségét a hallgatók az egyetem berkein belül keresik, ami, mint elvárás itt meg is fogalmazódik. A nyugodt élet, „ellenni" az egyetemen, valamint a TDK, mint elvárás nem jelentkezik jelentős mértékben.

Hallgatók válaszai azzal a kérdéssel kapcsolatban, hogy milyen szakmában szeretnének dolgozni a végzés után, megerősítették a feltételezésünket azzal kapcsolatban, hogy nem elég pozitív a hallgatók hozzáállása a választott szakmájukhoz. A hallgatók mindössze 52,9 \%-a szeretne a szakmájának megfelelö, (vagy azzal kapcsolatos) he- 
lyen dolgozni. A fent említett kérdésre, a hallgatóknak csak mindössze negyedétől kaptuk a szakjának megfelelő szakmában való elhelyezkedésére vonatkozó választ. Ez az alacsony arány, feltételezésünk szerint, a szakma értékeinek nem megfelelő elismerésével és az alacsony állami fizetéssel kapcsolatos. Eközben a hallgatók 9,4\%-a szeretne dolgozni olyan szakmában, amely nem függ össze a szakjával. A hallgatók 4,3 \%-a válaszolt nemmel, mert még tanulni akar egy újabb szakon (újabb szakmát). Ennek a számnak az alacsony értéke feltételezésünk szerint azt tükrözi, hogy kevesen szereznek másoddiplomát az első diploma megszerzése után.

\section{4. ábra A hallgatók tanulással és az egyetemi évekkel kapcsolatos elvárásai.}

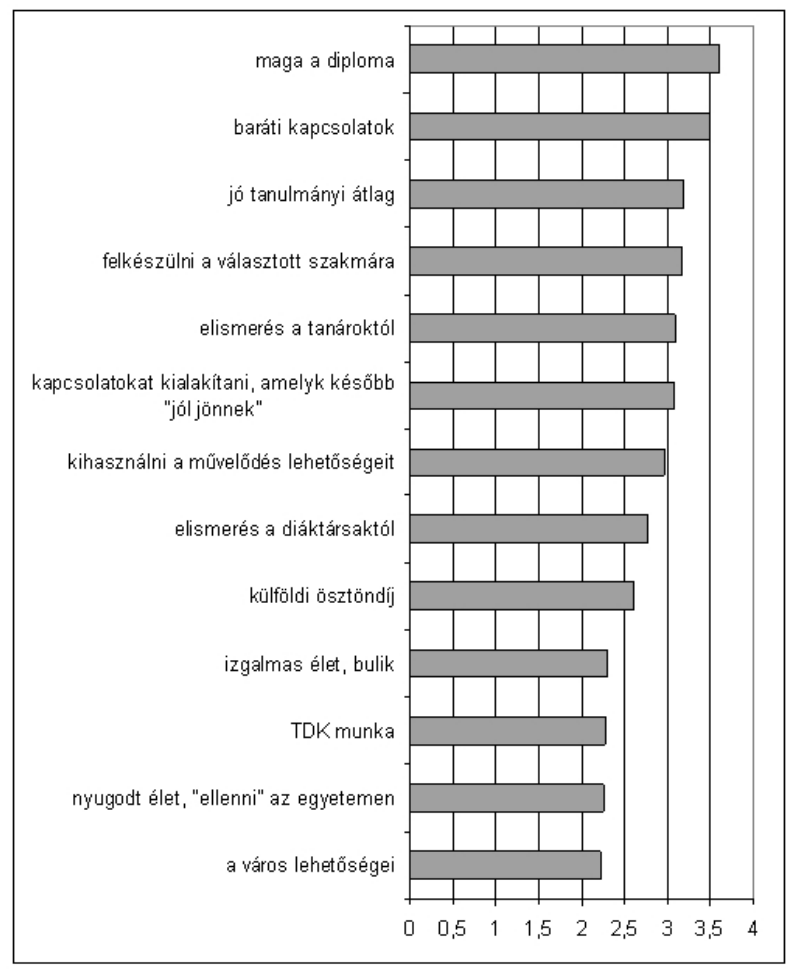

Forrás: A TÁMOP 4.2.2-B pályázati kutatás adatbázisa

A régiónkra inkább az jellemző, hogy a hallgatók párhuzamosan két szakon is tanulnak, így a másoddiplomát az elsővel párhuzamosan szerzik. Azok aránya, akik számára a magas fizetés a meghatározó ( 5,8 \%,) és akik nem nagyon gondolkodtak erről (2,9 
\%), nem túl magas. Ez a viszonylag alacsony arány véleményünk szerint nem tükrözi megfelelő mértékben a hallgatók rászorultságát. Ennek miértjét megindokolni nem könnyü. Ez azzal is összefügghet, hogy egyrészt a hallgatóknak még papíron is nehéz anyagi problémáiról vallani, másrészről a szülők háztartásában élve, anyagilag általuk támogatva, nem érzik ennek a tényezőnek az égető szükségét. A hallgatók mindössze 4,3\%-a döntött az "egyéb" válasz mellett, de mivel nem fejtette ki részletesen ennek tartalmát, ennek elemzését a találgatások elkerülése végett nem tartjuk indokoltnak. Nem köti össze a jövőjét a választott szakmájukkal a hallgatók 8,7 \%-a, ők azok, akik külföldön szeretnének tanulni és azok, akik posztgraduális képzésben kívánnak részt venni. Ez utóbbiak száma 4,3\%. A külföldön való tanulás a hallgatók körében azért alacsony, mert tapasztalataink szerint, egyfelől sokuk nem rendelkezik megfelelő magabiztossággal a nyelvtudását illetően, sokuk nyelvtudása pedig rendkívül alacsony. Habár a tapasztalatunk azt mutatja, hogy van a hallgatóknak egy jelentős hányada, aki beszél idegen nyelveket, azonban független intézmény által kiadott nyelvvizsga hiányában, ez nem sokat számít. Különösen, ha a nyelvvizsga mint követelmény szerepel a jelentkezésnél. Így nem csoda, hogy sok esetben a hallgatók külföldi felsőoktatási intézményekbe való jelentkezése elmarad. A másik ok az anyagiak (hiánya) miatti „röghözkötöttségben" rejlik.

\section{A SZAKMA ÁlTAL, AZ EGYETEM ELVÉGZÉSE UTÁN BIZTOSÍTOTT LEHETŐSÉGEK}

Fontos kérdéseket feszeget a kérdőív következő blokkja. A válaszadók a jelenlegi szakja/szakmája által, a társadalmi érvényesülés során biztosított lehetőségeket értékelték egy tízfokozatú skálán, ahol az 1-es a legkevésbé, a 10 - es a leginkább biztosítottat jelenti. (2. táblázat)

A válaszadók szerint a szakma által biztosított lehetőségek közötti rangsorban az első helyen a jövő biztosítása szerepel (átlagos pontszám 6.7). Ebben az előkelő helyezés ben benne van a hallgatóknak azon reménye, hogy diplomával van esély arra, hogy állást találjanak és berendezkedjenek az életben.

Az emberi megbecsülés (átlagpontszám 6.6) a második helyen szerepel. Véleményünk szerint ez jól mutatja a diplomás emberek presztízséről kialakult vélemény elterjedettségét a hallgatók körében és a társadalomban. A harmadik helyen szereplö érdekérvényesítő képesség (átlagpontszám 6.0) megszerzése inkább az önmegvalósítás lehetőségét vetíti elő, semmint az érvényesülést (átlagos pontszám 5.5) vagy hatalmat (átlagos pontszám 4.9). Érdekes, hogy a jövedelem mindössze a 7. pozíciót foglalja el a rangsorban (átlagos pontszám 5.5), ennek vélhető okára már utaltunk a korábbi elemzésnél. Emellett a hallgatók kevés lehetőséget látnak arra, hogy önállóan hozzanak döntéseket a jövőben. Erről tanúskodik az autonómia átlagos pontszáma (5.1). Az értékeket tekintve itt is utalhatunk rá, hogy mindez összhangban van a Super -kérdőívvel végzett munkaérték-preferencia vizsgálat eredményeivel, melyről a kötet más tanulmányaiban olvashatnak. 
2. táblázat A szakma által biztosított lehetőségek sorrendje és skála átlaga.

\begin{tabular}{|c|l|c|}
\hline Hely & A szakma mennyire biztosítja & Átlag \\
\hline 1. & A jövőjét & 6,7 \\
\hline 2. & Az emberi megbecsülését & 6,6 \\
\hline 3. & Az érdekérvényesítő képességét & 6,0 \\
\hline 4. & A presztízsét & 5,8 \\
\hline 5. & A közéleti szerepvállalását & 5,6 \\
\hline 6. & Az érvényesülési lehetőségeit & 5,5 \\
\hline 7. & A jövedelmi lehetőségeit & 5,5 \\
\hline 8. & Az autonómiáját & 5,1 \\
\hline 9. & A hatalmát & 4,9 \\
\hline
\end{tabular}

Forrás: A TÁMOP 4.2.2-B pályázati kutatás adatbázisa

\section{A VÁlaszTotT SZAK MEGFELELÉSE}

Azzal kapcsolatban, hogy mai ismereteik alapján mennyire felel meg a szak a hallga tók számára különböző szempontokból, a válaszadók egy tízfokozatú skálán a következő válaszokat adták melyeket a 3. táblázatban közlünk.

3. táblázat A szak különböző szempontoknak való megfelelésének rangsora .

\begin{tabular}{|c|l|c|}
\hline Hely & Szempontok & Átlag \\
\hline 1. & Érdeklődés & 7,8 \\
\hline 2. & Képességeinek & 7,5 \\
\hline 3. & Távolabbi életcéljának & 7,4 \\
\hline 4. & Tudásának & 7,3 \\
\hline 5. & Korábbi elvárásainak & 6,9 \\
\hline
\end{tabular}

A 3. táblázatban bemutatott skálaátlagok magasak, ami azt mutatja, hogy a hallgatók véleménye kedvező a szakkal kapcsolatban, illetve, hogy nem csalatkoztak saját választásukban. Az eredmények azt mutatják, hogy a szak nagymértékben megfelel a táblázatban 
felsorolt területeken. Az, hogy az első helyen van a hallgatók érdeklődésének való megfelelés (átlagos pontszám 7,8) azt mutatja, hogy a hallgatók úgy vélik, pályaválasztásuk megalapozott volt, beigazolódott a helyes döntésük. Az, hogy magas átlagértéket mutat a képességnek és a tudásnak való megfelelés, szerintünk a hallgatók megelégedettségét jelzi a szakon uralkodó követelményrendszerrel szemben, amit összhangban éreznek a képességeikkel és tudásukkal. A távolabbi életcélok (átlagpontszám 7,4) harmadik helyezése a szak iránt bizalmat mutatja éppúgy, mint a korábbi elvárásoknak való megfelelés, ami csak alig valamennyivel alacsonyabb skálaátlagot mutat.

\section{A JÖVÖBENI MUNKÁRA VONATKOZÓ ELKÉPZELÉSEK}

A kutatásunk során alkalmazott kérdőív dimenziói kiterjednek az egyetem elvégzése utáni időszak értékelésére is. Érdekes volt látni a hallgatók konkrét elképzeléseit a jövőbeni munkájukat illetően. Arra a kérdésre, hogy van e már elképzelése arról, hogy végzés után milyen településen dolgozna, csak a válaszadók 54,3\%-a tudott válaszolni.. Elég nagy hányaduk $(39,1 \%)$ nemmel tudott csak felelni, ami a hallgatók választással kapcsolatos nehézségeiről szól úgy általában. A hallgatók $6,5 \%$-a egyáltalán nem tudott választ adni a kérdésre. A válaszadók közül 12,3\% szeretne dolgozni Ungváron, 37,1\% a más városokban, 19,1\% - külföldön, és 7,9\% - Magyarországon. A megkérdezettek majdnem fele $(48,4 \%)$ szeretne állami alkalmazott lenni, a többi egyéni vállalkozó, vagy beosztott $(6,3 \%)$. Az, hogy a hallgatók összesen majdnem $60 \%$-a nem külföldön és nem Ungváron, a területi központban szeretne dolgozni, egyfelöl azt mutatja, hogy a hallgatók más városokból, más településekről érkeztek és azt is jelenti, hogy otthon látják biztosítottnak a jövőjüket, közel a szülői házhoz. Az állami alkalmazott, valamint a vállalkozó arányai közel esnek egymáshoz, ami az egyéni vállalkozás teljes elfogadottságát tükrözi a régióban. Aggasztó tényként értékeljük azonban azt, hogy a hallgatók csupán 6,2 \%-a szeretne beosztottként dolgozni. A tapasztalat azt mutatja, hogy hallgatóink vezetői állásba szeretnének kerülni közvetlenül az egyetem befejezése után, habár azt a munkagyakorlat és vezetöi gyakorlat hiánya nem teszi indokolttá. Ez összefügg azzal, hogy általában magas presztízst tulajdonítanak a választott pályának.

\section{A SZAKOK ÚJBóLI VÁLASZTÁSA}

A szak újbóli választására vonatkozó kérdésre a megkérdezettek háromnegyede $(73,6 \%)$ igennel válaszolt, ami, a hallgatók szakkal való megelégedettségét tükrözi, s teljesen összhangban van az előző, a szak megfelelésére vonatkozó kérdéskör eredményeivel. A választás indokaival kapcsolatban a legmarkánsabban az jelenik meg, hogy a szak, a szakma jó lehetőségeket biztosít. A hallgatók ugyancsak háromnegyede $(76,1 \%)$ választotta ezt a választ. A hallgatók választása alapján csökkenő sorrendbe állítottuk további indokokat, melyek egyébként az előzőekben ismertetett indokhoz képest elenyésző gyakorisággal fordulnak elő. A tervekre és az érdeklődésre vonatkozó választ aránylag sok hallgató választotta, mindkét ráta $10 \%$ feletti. A sereghajtó indokok a jó tanárok $(3,5 \%)$ 
és a képzés színvonala (3,5\%) voltak. Az inverznek mondható kérdésre, hogy "Miért nem választaná ezt a szakmát?", a válaszadók csaknem fele nem tudott válaszolni (49,7\%). A válaszadók 22,7\%-ának megváltoztak az elképzelései, a hallgatók 12,0\%-a nem azt kapta, amit várt. Mindössze 2,7\% tartja úgy, hogy a követelmények túl magasak és további $4 \%$ véli azt, hogy az oktatással kapcsolatos az elvárásai nem felelnek meg a befektetett erőfeszítéseknek. A megkérdezettek töredéke (1,3\%) számolt be arról, hogy nem érzi magát jól. Az, hogy a válaszadók fele, nem tudott válaszolni a fent említett kérdésre azt feltételezi, hogy nincs ellenére a szak és nincs ellenérve azzal szemben, miért ne választaná újra ezt a szakot. Ismeretes, hogy a pályaelhagyók száma Ukrajnában nem hivatalos becslések szerint nagyon magas, és az, hogy az általunk megkérdezettek mindöszsze 22,7 \%-a válaszolt úgy, hogy megváltoztak az elképzelései, véleményünk szerint azt mutatja, hogy leggyakrabban nem a szakember, hanem a munkaerőpiac szabja a lehetőségeket és kényszerít pályaelhagyásra.

\section{ÖSSZEGZÉS}

A hallgatók jövőbeli pályaképének tanulmányozása során megállapításra került, hogy tényezők tucatjai befolyásolják a hallgatók pályaválasztását. Az eredmények azt mutatják, hogy ezen tényezők hatékonysága a hallgatók pályaválasztásánál nagyon különböző. Kulcsfontosságúnak bizonyult a szak kiválasztásánál a hallgatók jövőbeni terveinek megvalósulása, valamint az, hogy a felvételi vizsgák a hallgatók kedvenc tantárgyaiból legyenek. A választásnál a hallgatók a legfontosabb információforrásként a tanárok, a szülők és a felvételi tájékoztatóból kapott információt jelölték meg..

Az összes kar hallgatója előnyben részesíti a diploma megszerzését és a munkanélküliség elkerülését. A válaszadók több mint a felét a választott szak érdekli. A felsőoktatási intézményt, a felmérés eredményei szerint, a válaszadók azért választották, mert ezen a területen ez a szak a legjobb, és ennek van a legjobb híre, hírneve. A válaszadók többsége ezen a területen kíván dolgozni a jövőben is és úgy véli, hogy az általa választott szak magas presztízsü, választott szakmája összefügg a szakjával, és a munkavállalásnál széleskörü választást biztosít.

A hallgatók pályaválasztással kapcsolatos megelégedettségének állapota valamint, a szakmájukban továbbra is dolgozni akarók alacsony aránya a fiatalok felsőoktatásban való „ellevésének” tömegességét mutatja. Ennek következtében a pályaválasztást sok esetben a véletlen, nem pedig az érdeklődés befolyásolja.

Kutatási téma magas színtủ gyakorlati érdeklődést váltott ki körünkben, ezért folytatása és a válaszadók széles skálájára való kiterjesztése reprezentatív minta alkalmazásával indokolt nemcsak Kárpátalja, hanem Ukrajna más rangos felsőoktatási intézmény esetében is. Érdekes lehet továbbá a humán és a müszaki karok hallgatói profeszszióképének összehasonlító elemzése valamint, a hallgatók tanulással kapcsolatos motivációi kutatása során meghatározott összefüggéseinek vizsgálata is. 


\section{Felhaszánat irodalom}

1. Balogh László - Fónai Mihály (2003): Tehetséggondozási formák a Debreceni Egyetemen. Magyar Felsőoktatás 13: (4-5-6) 13.-15 o.

2. Bourdieu, P. (1998): Gazdasági tőke, kulturális tőke, társadalmi tőke. In: Lengyel György - Szántó Zoltán (szerk.): Tőkefajták: A társadalmi és kulturális erőforrások szociológiája. Budapest: Aula Kiadó, 155-176. o.

3. Fónai Mihály (2009): A Debreceni Egyetem Tehetséggondozó Programjába került hallgatók rekrutációja és a szakok értékelése. In: Karlovizt János Tibor (szerk.): Speciális kérdések és nézőpontok a felsőoktatásban. Budapest: Neveléstudományi Egyesület, 2009. pp. 49-65. (ISBN $978-963-88422-2-0$ )

4. Fónai Mihály (2010): Hallgatók professzió-képének elemei. In: Kozma Tamás - Perjés István (szerk): Új kutatások a neveléstudományokban. Többnyelvőség és multikulturalitás. Budapest: Aula Kiadó, pp. 227-246.

5. Fónai Mihály - Márton Sándor (2010): A tehetséggondozó program hallgatóinak professzió-képe - egy sokváltozós modellmagyarázat lehetséges elemei. In: Kozma Tamás - Ceglédi Tímea (szerk.): Régió és oktatás: A Partium esete. Debrecen, CHERDHungary: Center for Higher Education Research and Development - Hungary. pp. $147-153$

6. Kiss János - Fónai Mihály - Fábián Gergely (2001): Szociális és egészségügyi szakos hallgatók szakmával kapcsolatos tudattartalmának összehasonlító vizsgálata. In: Dienes E - Takács Á (szerk.): XV. Munka-és Szervezetpszichológus szakmai napok Esztergom, Budapest: Országos Munkaügyi Kutató és Módszertani Központ.144-159. o.

7. Márton Sándor - Mező Ferenc - Balogh László - Fónai Mihály (2006): A Debreceni Egyetem Tehetséggondozó Programja és beválogatási szempontjai. In: Balogh L Mező F - Tóth L (szerk.): A Debreceni Egyetem Tehetséggondozó Programjának II. Konferenciája. Tanulmányok. Debrecen: Debreceni Egyetem 7-12. o.

8. Pro koncepciju szerednyoji zagalynooszvitnyoji skoli Ukrajini, 1992, Informacijnij zbirnik Minyisztyersztva Narodnoji Oszviti Ukrajini, 1992 N 4: 1-8 (Orosz Ildikó. Magyar nyelvá oktatás Kárpátalján. http://mek.oszk.hu/01900/01946/html/) Munkalélektani Koordinációs Tanács továbbképző előadássorozat 2. kötet Budapest 